\title{
The analysis of problems, causes, and efforts to resolve problems in the service of covid-19 patients at the army hospital in Padang City
}

\author{
Adila Kasni Astiena ${ }^{1 *}$, Mohamad Reza ${ }^{2}$, Fitri Sari Susanty ${ }^{2}$, and Jonsriwanto ${ }^{3}$ \\ ${ }^{1}$ Departement of Administration and Public Health Policy, Faculty of Public Health, Andalas University, Indonesia \\ ${ }^{2}$ Public Health Study Program Faculty of Medicine, Andalas University, Indonesia \\ ${ }^{3}$ Reksodiwiryo Hospital, Padang, Indonesia
}

\begin{abstract}
During the adaptation period to new habits, every hospital needs to make some changes to prevent the transmission of covid infections in the hospitals. The Ministry of Health has issued a technical guide that should be a guide for every hospital. The Army Hospital in Padang City has a different communication flow and chain of command from hospitals owned by health institutions. This study aims to analyze efforts to optimize services for COVID-19 patients during the adaptation period for new habits. The research design is qualitative. The study was conducted in OctoberDecember 2020. The unit of analysis is an emergency department for the Covid and non-covid services. Data were collected by interview, observation, and document review. The results showed that emergency room services were not following the technical guidelines for hospital services during the adaptation period for new habits. Some of the causes are seen in terms of input, ie. personnel, room and equipment, funding, and patient behavior as well as from the screening process. Steps that can be taken to optimize services are to create a service flow, install zone barriers, move screening rooms and improve patient education and carry out periodic monitoring and evaluation.
\end{abstract}

\section{Introduction}

Every sector of life has changed since the declaration of Covid-19 as a global pandemic by WHO in March 2020. After the announcement of the first case of Covid-19 in March 2020, the government has issued Presidential Decree Number 12 of 2020 concerning Determination of Non-Natural Disasters for the Spread of Corona Virus Disease. 2019 (COVID-19) as a National Disaster [1]. Coronavirus is spreading rapidly in Indonesia. Indonesia is a country with the highest number of deaths due to Covid-19 in the world. Health worker mortality in Indonesia is also the highest in the world. Until August 2020 , the death of health workers in Indonesia reached 350 people.

The Covid-19 pandemic has changed every activity in people's lives, including changes in health care organizations. This change aims to minimize the risk of spreading Covid-19 by implementing the Adaptation of New Habits in the community. Health facilities such as health centers, clinics, and hospitals are very at risk of becoming clusters of the spread of the Sar Cov-2 virus. On the one hand, health care institutions are trying to save Covid-19 patients, but on the other hand health workers

\footnotetext{
*Corresponding author: adila@ph.unand.ac.id
}

and visitors are faced with a high risk of contracting Sar Cov-2.

To anticipate this, the government has issued guidelines for handling COVID-19 for local governments, health service facilities such as puskesmas, and hospitals [2]. Especially for the prevention of transmission of Sar Cov-2 in hospitals, the government has issued a technical guide for hospital services during the adaptation period of new habits [3]. Through the implementation of this guide, it is hoped that hospitals will optimize service delivery to COVID-19 patients and otherwise be able to prevent transmission to other patients, health workers, and visitors.

The city of Padang is currently in the Covid-19 red zone due to a significant increase in cases. The Army Hospital is a reference for COVID-19 patients in the city of Padang. This hospital is under the command of the Ministry of Defense and Security, unlike other hospitals under the Ministry of Health. This is a challenge in providing health services, where on the one hand hospitals follow the military chain of command but on the other hand need to follow service standards from the Ministry of Health. This hospital not only serves soldiers and their families but also serves civilians. Even the number of patients from civil society exceeds that of patients from 
the army. If not bridged properly, this can have an impact on the quality of health services.

Assessment of the quality of emergency unit services is a crucial part of every hospital. Patients enter the door of inpatient services after going through the Emergency Department (ER) or outpatient services. The ER is the main gate of community assessment of the high or low quality of service at a hospital. Thus, the ER has several requirements and quality indicators that must be met, so that a hospital can provide quality health services. However, with the pandemic, the ER service requirements have several modifications that aim to prevent the risk of Covid-19 transmission in hospitals. In reality, there are several problems in the implementation of emergency services during the pandemic. Service adaptation must adapt to the pandemic situation so that not all hospitals have the readiness to adapt to the pandemic situation. This creates problems in the quality of health services that can endanger the safety of patients, health workers, and visitors.

During this Covid-19 pandemic, efforts to identify problems, analyze the causes of problems, and find solutions are very crucial in efforts to improve service quality. The Army Hospital in providing health services to Covid-19 patients also guides government regulations and the Technical Guidelines for Hospital Operations during the adaptation period of new habits. From the preliminary study, it is known that Covid-19 services are still not optimally implemented with several service problems in the emergency unit and inpatient units.

The purpose of this study was to analyze the problems of service for Covid-19 patients at the Army Hospital in Padang City by identifying problems, looking for causes of problems, exploring problem-solving steps, and making a model plan for monitoring and evaluating patient services. Problem identification models, problemcausing analysis, problem-solving steps, and problemsolving monitoring and evaluation plans can be used by management as tools that can be used in decision-making, especially related to handling pandemics at home that are across the Ministry, namely the Ministry of Defense and Security.

The name of the author concerned. Please ensure that affiliations are as complete as possible and include the country.

\section{Literature Review}

Hospital visitors are screened first before entering the ER or Outpatient Installation. Screening is a process of evaluating and screening patients and visitors to separate suspected Covid-19 patients from non-suspect Covid-19 patients, health workers, and visitors. Patients are declared suspect of Covid-19 if they meet at least 1 criteria for an epidemiological history or 1 clinical symptom. Screening aims to reduce the risk of exposure to Covid-19 to patients and health workers. Requirements include building standards, location, and flow of patients so that the goals and objectives of screening can be achieved [2].
Buildings for Covid-19 screening can be in the form of temporary buildings that already exist, can be simple tents, but must have adequate natural ventilation. The screening location should be as close as possible to the main entrance so that it can be accessed by all visitors, avoiding the accumulation of queues and ensuring the safety and security of visitors. The flow of visitor movement should be one-way with separate entrances before screening and exits after screening to avoid the risk of COVID-19 transmission. Patients who are declared Suspected Covid-19 are then triaged to determine whether they require immediate medical intervention, wait, or be referred to another hospital [2].

The requirement for the location of the triage room is to be at the entrance before entering the Covid-19 ER waiting room. At the triage location, it is necessary to have hand hygiene facilities, in the form of a sink, soap, and running water. In addition, there is a need for information and education media in the form of brochures and posters related to Covid-19 prevention. Officers need to be aware of visitors with symptoms of cough, fever, shortness of breath, and difficulty breathing [4]. Hospital services in the pandemic era also need to pay attention to space zoning, namely the division or grouping of service rooms based on the similarity of activity function characteristics. This is done to prevent the spread of COVID-19 in hospitals. The Covid-19 zone includes the Covid special service area and the Covid Special support area. Among the COVID-19 special service, areas are the emergency room and the treatment room.

According to the Regulation of the Minister of Health Number 47 of 2018 concerning Emergency Services, emergency services are services provided to patients in an immediate time to save lives and prevent disability [5]. The physical requirements of the emergency room building are related to the building area, location, entrance, and exit, vehicle entry and exit routes, special areas for ambulance parking, arrangement of room flows, and room requirements. The emergency room must also have a triage room, which is room to carry out a process of sorting patients based on the severity of the injury or disease and determining the type of treatment [6].

There are 3 options in optimizing patient care during the adaptation period to new habits [3].

1. First, the Covid and Non-Covid rooms are in separate locations, but if there are problems with limited room availability, this can be done by providing temporary or permanent barriers marked with clear special markers and adhering to a one-way lane system.

2. Second, dividing the number of special human resources for Covid-19 and Non-Covid-19 services. However, if the number of human resources is not sufficient, then a schedule/division of picket shifts is carried out between ordinary services and COVID19 special services.

3. Third, if the availability of the room does not allow for zone separation at all, then arrangements are made for service schedules, division of service shift hours or service days followed by decontamination and sterilization measures for both rooms and 
medical devices after providing services to COVID19 patients according to the rules applicable.

Emergency room patients who have symptoms of COVID-19 must be prioritized to wait separately in the room provided. Patients must remain in this waiting room and must not visit other parts of the hospital such as the treatment room, cafeteria, and so on [5]. The COVID-19 special ER area is an observation room or action room for emergency room patients with COVID-19 symptoms. This area is separated from the non-COVID-19 emergency room area through a permanent or temporary boundary. After entering the COVID-19 ER area, patients are not allowed to return to the non-COVID-19 ER area and officers are only allowed to enter and leave this area through the dressing room/ doning/doffing [2]. The arrangement of Covid-19 services that are carried out properly during a pandemic situation is expected to improve the quality of Covid-19 services to the community to heal and prevent transmission to officers and fellow patients and visitors.

\section{Method}

The design of this research is qualitative. The study was conducted for 4 months from October 2020 to February 2021. The research variables were Problem Identification, Causes of Problems, Problem Solving, Monitoring and Evaluation, and Follow-up Plans for Optimizing Emergency Room Services during the adaptation period of new habits. Data were collected by interview, observation, document review, and FGD methods. The research informants were 7 people, namely the Head of the Hospital, Head of Outpatient Installation, Head of the Emergency Room, 1 doctor, 1 nurse, and 2 patients. Data analysis was carried out thematically. The validity of the data was tested by the source triangulation method and the triangulation method.

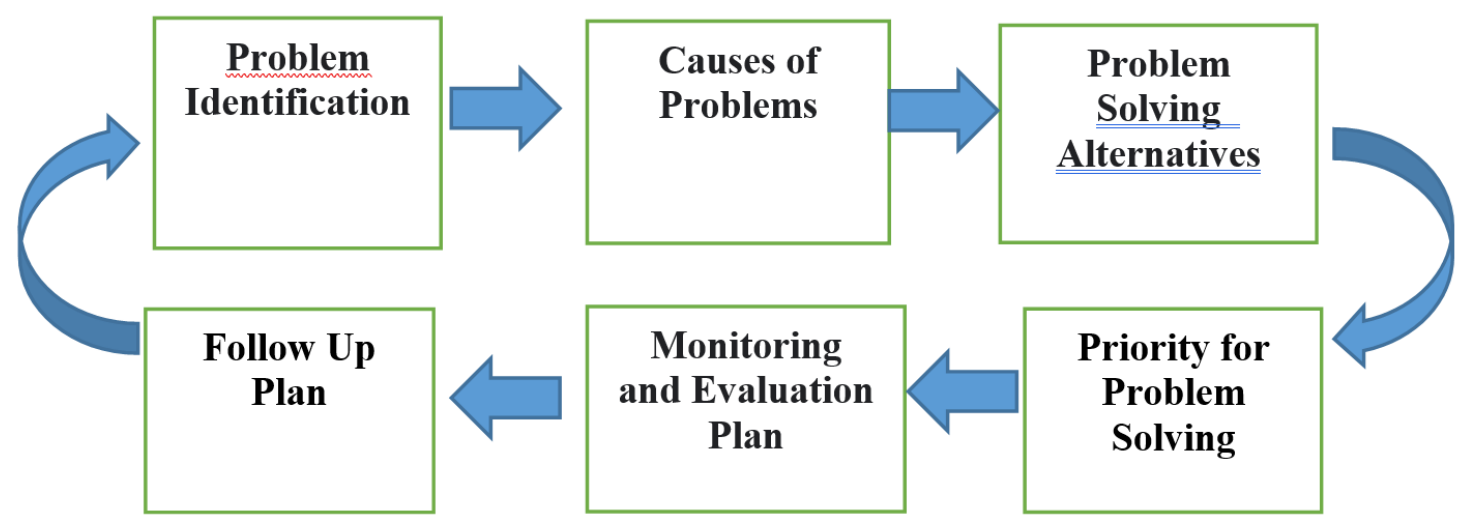

Fig. 1. Research Frameworks

\section{Results}

\subsection{Problem Identification}

From the results of observations, interviews, and document review, the results of problem identification were obtained

\subsubsection{Covid patient services in the ER are not up to standard.}

From the results of direct observations and interviews with ER officers, data showed that the patient screening room was located in one room with the ER patient registration counter which was separated by a barrier made of glass. This screening room has 2 beds, but there is no barrier between the beds, so there is a high risk of causing Covid transmission to non-Covid patients.

Screening is carried out by a nurse or doctor on duty using a rapid assessment form. After screening, the patient is placed in the appropriate room, namely the Covid isolation room for Covid patients and the triage room for non-covid patients. The Covid isolation room and triage room are located next to the screening room. The Covid isolation room and the triage room have the same entry route.

Officers enter the Covid isolation room using PPE. If the patient is examined in the laboratory, the sample will be taken by the labor officer in the Covid isolation room. However, if a Covid patient requires a radiological examination, the patient will be taken to a radiology room using an isolation chamber. The Army Hospital does not yet have a portable X-ray, so Covid and Non-Covid patients must take turns to carry out examinations. After X-ray examinations are carried out on COVID patients, the radiology room will be decontaminated and nonCOVID patients may not conduct examinations. This decontamination process takes about 1 hour. If there are non-COVID patients who need X-rays, they have to wait. Procurement for this portable X-ray has been proposed but has not yet been realized.

Some patients who come to the ER behave dishonestly regarding the complaints and symptoms of Covid. Patients who should have been placed in the Covid isolation room were finally placed in the triage room. This increases the risk of transmitting Covid to non-Covid patients. After laboratory and radiological examinations, patients with suspected Covid-19 are given education for self-isolation if they only experience mild symptoms and 
do not require treatment. Patients who need Covid treatment will be transferred to the Covid treatment room using an isolation chamber.

Several Covid patients are recommended to be treated but are not willing to be treated and choose to go home of their own free will. Patients who agree to be treated will be escorted by officers to the Covid treatment room. There is no special route to the Covid special treatment room. Access from the ER to the radiology examination room has the same path as Non-Covid patients, visitors, and hospital staff.

The hospital already has an isolation chamber, which is a means of transporting patients to carry out radiological examinations and move to the COVID-19 isolation treatment room. There are no posters, banners, brochures, or so on about Covid in the emergency room so that patients and visitors get limited information.

There are 3 service shifts in the ER where the number of doctors on duty is 3 people per shift and 5 nurses per shift. The effective working hours of Covid services are 140 hours per month. Based on the Ministry of Health, the minimum need for general practitioners is calculated by the formula $=(3$ shifts $\times 24$ hours $) \times 30$ days divided by 140 hours of optimal service $=16$ people. The number of nurses on one shift is 5 people. The minimum need for nurses is calculated using the formula $=(5 \times 24) \times 30$ days divided by 140 hours $=26$ people.

\subsubsection{Covid Isolation Treatment Is Not Up To Standard}

The capacity of the Covid patient treatment room at the Army Hospital is 68 beds divided into 2 locations, namely Room V and the Pavilion Building. The Covid treatment room is not equipped with negative pressure or HEPA filters as air filters. All COVID patients treated at the Padang City Army Hospital are patients with mild to moderate symptoms. Patients with severe symptoms to $\mathrm{M}$ Djamil Hospital. Because the Army Hospital does not yet have a ventilator.

The division of service zones at RST Padang already exists but is not informed to patients/visitors. There is no barrier between the red zone and other zones. No officers are guarding the red zone, or warning signs so that nonCoivid patients and visitors enter the zone without knowing it.

\subsection{Prioritizing Problems}

Priority problems using the CARL method with a weighting of 1-5 values. CARL itself has the meaning:

1. C (Capability), namely the availability of resources (funds, facilities, equipment)

2. An (Acceptability), namely convenience, the existing problems are easy/can be overcome with the availability of methods/methods/technology as well as implementation support.

3. $\mathrm{R}$ (Readiness) which is the readiness of the implementing staff as well as the readiness of targets such as expertise or ability and motivation
4. L (Leverage) that is how much influence one criterion with another in problem-solving.

Furthermore, to determine the priority of the problems identified by making a CARL criteria table and scoring with a range of 1 to 5 , where $5=$ very important, $4=$ important, 3 = quite important, 2 = not important, $1=$ very unimportant. And the priority is the one with the highest value after each criterion is multiplied $(\mathrm{CxAxRxL}=$ Value). The value is determined based on the results of the FGD with the management with the results shown in table 1 . Based on table 1, the priority problem is "Covid patient services in the emergency room are not up to standard".

Tabel 1. The Problem Priority in the Covid Services in The Army Hospital

\begin{tabular}{|c|l|c|c|c|c|c|c|}
\hline No & Problem & C & A & R & L & Score & $\begin{array}{l}\text { Priority } \\
\text { Number }\end{array}$ \\
\hline 1 & $\begin{array}{l}\text { The } \\
\text { service for } \\
\text { Covid } \\
\text { patients in } \\
\text { the ER is } \\
\text { not up to } \\
\text { standard }\end{array}$ & 5 & 5 & 4 & 5 & 500 & I \\
\hline 2 & $\begin{array}{l}\text { Patient } \\
\text { care in the } \\
\text { Covid } \\
\text { isolation } \\
\text { ward is } \\
\text { not up to } \\
\text { standard }\end{array}$ & 4 & 5 & 4 & 5 & 400 & II \\
\hline
\end{tabular}

\subsection{Cause of Problem}

To help determine the possible causes of the problem, the Ischikawa diagram is used. Ischikawa diagram is a tool to describe several causes of problems in detail based on input aspects consisting of man, money, material, method, and machine. The cause of the problem can be described as follows:

\subsubsection{Man}

The cause of the problem in the Covid service come from Man Aspect, due to ;

1. The patient is not honest in providing information about the complaints experienced. Patients who suffer from COVID will be treated like ordinary patients in an ordinary room and after the results of laboratory and radiology examinations are obtained, it will be known that COVID-19. This patient is at risk of transmitting the disease to staff and other patients in the room.

2. Rejection of patients who do not want to be diagnosed as COVID patients.

3. Patients who have been diagnosed as COVID-19 patients sometimes deny their illness and even accuse 
the hospital of only looking for profit so that they refuse to be treated and ask to go home at their request. Some patients argue that they have the right to refuse to perform a service or action.

\subsubsection{Method}

1. The arrangement of the screening room in the ER is not up to standard

2. The location of the screening room is in the ER and there are no barriers between beds in the ER. This poses a high risk of transmitting COVID to noncovid patients.

3. The arrangement of the ER isolation room is not up to standard.

4. The IGD Covid isolation room is inside the ER and has the same route as the non-Covid patient triage room. There should be a different path between the isolation room and the patient triage room to avoid the transmission of Covid.

5. The flow of services for COVID patients in the ER uses the old flow

6. The flow of patient care in the ER still uses the old flow that does not include screening and triage in the ER. The channel is still asking for travel history to China, while the transmission of Covid in Padang City has been going on by local transmission.

\subsubsection{Material}

1. There is no portable $\mathrm{X}$-ray device yet

There is no portable X-ray device so that the examination for COVID and Non-COVID patients is carried out alternately. This causes the waiting time for ER radiology services to increase, thereby reducing the quality of health services.

2. No media information related to Covid was found There were no information media such as banners, billboards, or brochures that explained Covid, so other patients/visitors did not have sufficient understanding.

3. There is no warning for those who hinder the performance of the Health Officer

No information media was found, it could be in the form of banners containing laws and sanctions for those who try to hinder the performance of health workers in $p$. for patients who hinder the performance of health workers in handling Covid.

\subsubsection{Money}

Limited funds for the procurement of portable Xrays. The budget for handling Covid comes from the Army Hospital. There has been no financial assistance from other parties, both from the Ministry of Health and from the Regional Government regarding the handling of Covid.

\subsubsection{Market}

An increase in the number of COVID patients compared to the beginning of the pandemic. There has been a significant increase in Covid patients in Indonesia, including in West Sumatra Province

The description of the causes of the problem is described as follows; This problem is searched for the cause of the problem by describing it on the Ischikawa Diagram as shown in Fig. 2.

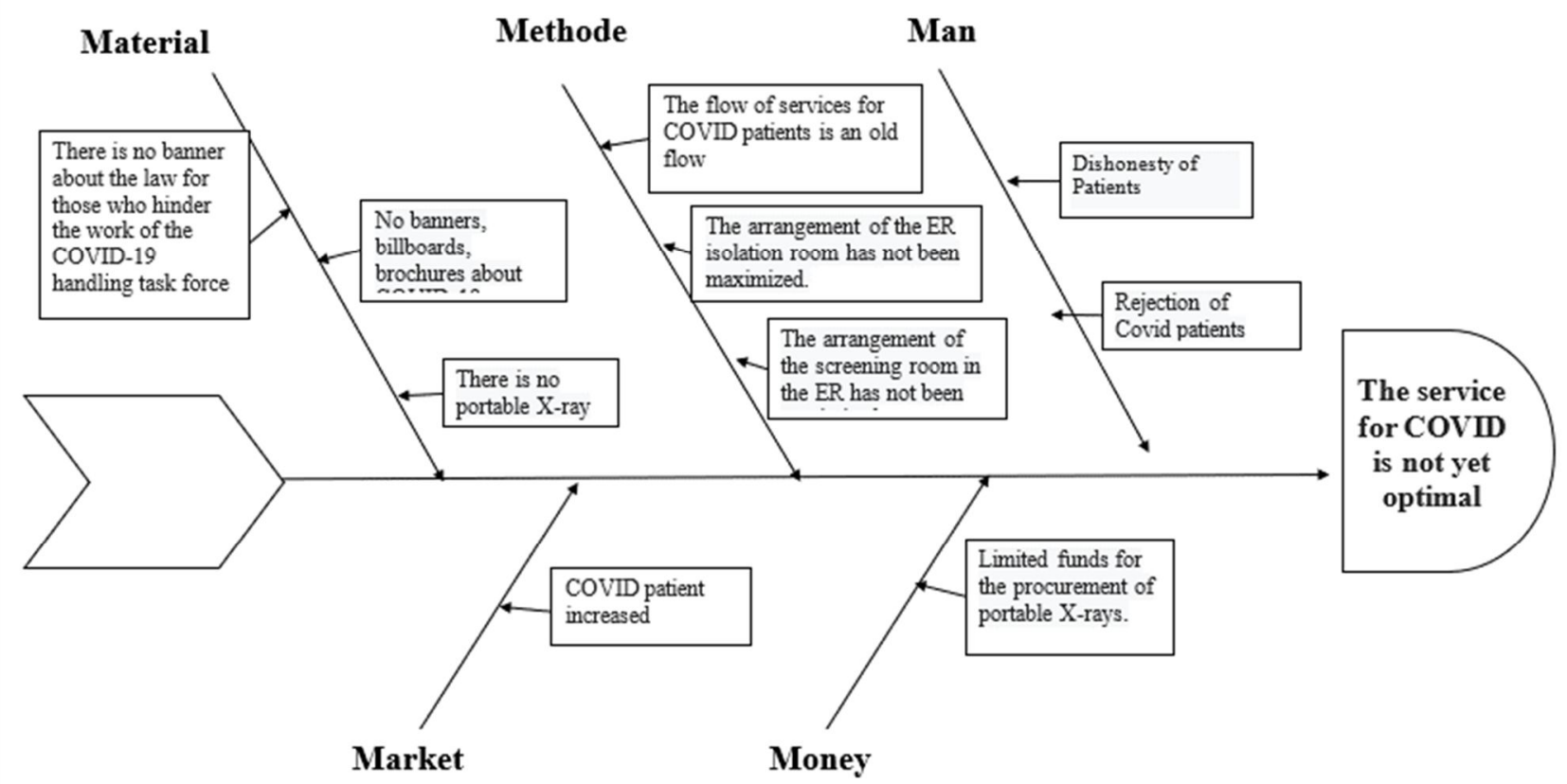

Fig. 2. Causes of the Problem 


\subsection{Troubleshooting Alternatives}

Table 2. Causes of Problem and Troubleshooting Alternative

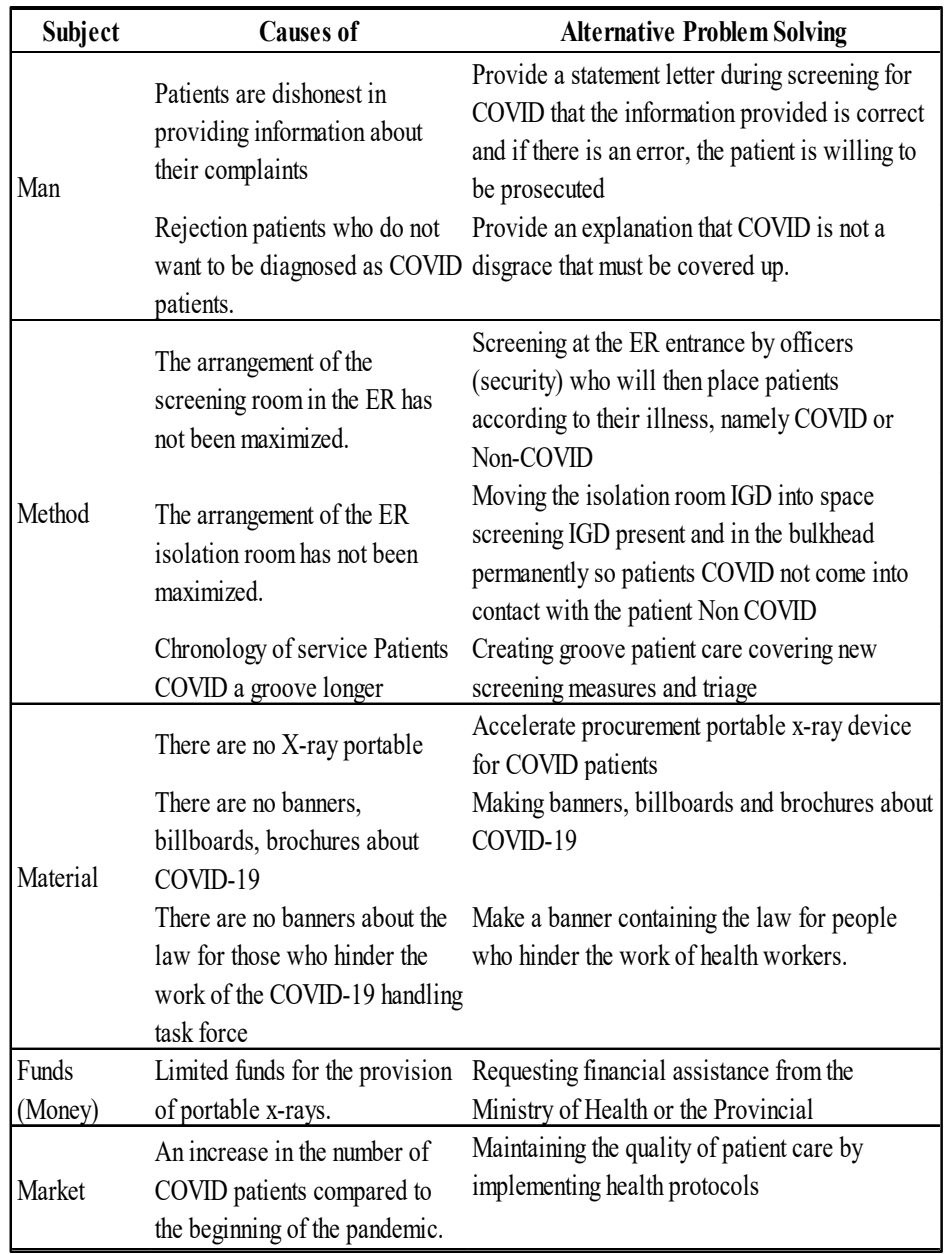

\subsection{Priority for Problem Solving}

The method used in determining the root of the problem is to continue the analysis of the fishbone diagram using the effectiveness/efficient method:

1. M (Magnitude): the magnitude of the problem that can be overcome

2. I (Important): the importance of a way out to solve the problem

3. V (Vulnerability): sensitivity (path accuracy) out for problems)

4. $\mathrm{C}$ (Cost) : Efficiency (Costs incurred)

$$
\text { Priority }(\mathrm{P})=\underline{M x I x V}
$$

Scoring for MIV :

1: Least effective

2: Ineffective

3: Less effective

4: Effective

5: Most effective
Scoring for $\mathrm{C}$ :

1: Most efficient

2: Efficient

3: Less efficient

4: Inefficient

5: Least efficient
Table 3. Problem Solving Priority

\begin{tabular}{|ccccccccc|}
\hline No & \multicolumn{1}{c}{ Activities } & M & I & V & C & Score & Priority \\
\hline 1 & 5 & 5 & 5 & 1 & 125 & I \\
2 & $\begin{array}{l}\text { Provide a statement letter } \\
\text { Provide an explanation that COVID is not a } \\
\text { disgrace which must be covered }\end{array}$ & 5 & 5 & 5 & 1 & 125 & I \\
3 & 5 & 5 & 5 & 2 & 62.5 & II \\
4 & $\begin{array}{l}\text { Patient Screening at the entrance } \\
\text { Moving the ER isolation room to an existing IGD }\end{array}$ & 5 & 5 & 5 & 2 & 62.5 & II \\
5 & $\begin{array}{l}\text { Create a new patient service flow including } \\
\text { screening and patient triage measures }\end{array}$ & 5 & 5 & 5 & 1 & 125 & I \\
6 & $\begin{array}{l}\text { Accelerating the procurement of portable X-rays } \\
\text { for COVID patients }\end{array}$ & 4 & 4 & 4 & 3 & 21.33 & IV \\
7 & $\begin{array}{l}\text { Making banners, billboards, brochures and others } \\
\text { regarding COVID-19 }\end{array}$ & 5 & 5 & 5 & 2 & 62.5 & II \\
8 & $\begin{array}{l}\text { Making banners about the law and sanctions if } \\
\text { preventing officers from carrying out COVID } \\
\text { response }\end{array}$ & 5 & 5 & 5 & 2 & 62.5 & II \\
9 & $\begin{array}{l}\text { Requesting financial assistance from the Ministry } \\
\text { of Health or the Province }\end{array}$ & 4 & 4 & 4 & 4 & 16 & V \\
10 & $\begin{array}{l}\text { Maintaining the quality of patient care by } \\
\text { implementing health protocols }\end{array}$ & 4 & 5 & 4 & 2 & 40 & III \\
\hline
\end{tabular}

Based on table 3, the authors take the top two priority scales for alternative problem solving as follows:

1. Provide a statement letter at the time of screening for COVID that the information provided is correct and if there is an error, the patient is willing to be prosecuted 
2. Explain that COVID is not a disgrace that must be covered

3. Creating a new patient care flow including screening and patient triage tindakan

4. Screening at the ER entrance by officers (security) who will then place the patient according to their illness, namely COVID or Non-COVID

5. Move the ER isolation room to the current ER screening room and in a permanent partition so that COVID patients do not come into contact with Non-COVID patients
6. Make banners, billboards, brochures, and others about COVID-19

7. Make a banner regarding the law and sanctions if it prevents officers from handling COVID

\subsection{Activity and Budget Plan of Action}

After the alternative solutions to the problem are determined, a work plan (the plan of action/POA) is prepared according to table 4

Table 4. Activity and Budget Plan of Action

\begin{tabular}{|c|c|c|c|c|c|c|c|}
\hline \multirow{2}{*}{ NO } & \multirow{2}{*}{ Activity } & \multirow{2}{*}{ Objectives } & \multicolumn{2}{|c|}{ Elements Involved } & \multirow{2}{*}{ Time/Place } & \multirow{2}{*}{$\begin{array}{l}\text { Person in } \\
\text { Charge }\end{array}$} & \multirow{2}{*}{$\begin{array}{c}\text { Budget } \\
\text { Plan (Rp) }\end{array}$} \\
\hline & & & HR & Facility & & & \\
\hline 1 & $\begin{array}{l}\text { Providing a statement } \\
\text { letter }\end{array}$ & $\begin{array}{l}\text { Prividing the correct } \\
\text { information about } \\
\text { covid }\end{array}$ & $\begin{array}{l}\text { Heads of Outpatient } \\
\text { room, Head of Room, } \\
\text { Doctor on duty, Nurse, } \\
\text { Screening officer }\end{array}$ & $\begin{array}{l}\text { Statement } \\
\text { Letter }\end{array}$ & $\begin{array}{l}\text { Every } \\
\text { service } \\
\text { hour/ER }\end{array}$ & $\begin{array}{l}\text { Head of } \\
\text { Outpatient } \\
\text { Installation, } \\
\text { Head of } \\
\text { Room } \\
\end{array}$ & $\begin{array}{l}\text { Does not } \\
\text { incur } \\
\text { additional } \\
\text { costs }\end{array}$ \\
\hline 2 & $\begin{array}{l}\text { Providing the } \\
\text { explanation that } \\
\text { COVID is not a } \\
\text { disgrace which must be } \\
\text { covered }\end{array}$ & $\begin{array}{l}\text { Understanding that } \\
\text { COVID is not a } \\
\text { disgrace }\end{array}$ & Doctor on duty & $\begin{array}{l}\text { Informed } \\
\text { consent }\end{array}$ & $\begin{array}{l}\text { Every } \\
\text { service } \\
\text { hour/ER }\end{array}$ & $\begin{array}{l}\text { Doctor on } \\
\text { duty }\end{array}$ & $\begin{array}{l}\text { Does not } \\
\text { incur } \\
\text { additional } \\
\text { costs }\end{array}$ \\
\hline 3 & $\begin{array}{l}\text { Creating a new service } \\
\text { flow including } \\
\text { screening and patient } \\
\text { triage measures }\end{array}$ & $\begin{array}{l}\text { The flow of patient } \\
\text { care is clear }\end{array}$ & $\begin{array}{l}\text { Head of Outpatient } \\
\text { Installation, Head of } \\
\text { Room, }\end{array}$ & $\begin{array}{l}\text { Flow of } \\
\text { patient } \\
\text { care }\end{array}$ & $\begin{array}{l}\text { December er } \\
\text { 2020/ER }\end{array}$ & $\begin{array}{l}\text { Head of } \\
\text { Outpatient } \\
\text { Installation, } \\
\text { Head of } \\
\text { Room }\end{array}$ & $\begin{array}{l}\text { Does not } \\
\text { incur } \\
\text { additional } \\
\text { costs }\end{array}$ \\
\hline 4 & $\begin{array}{l}\text { Conducting screening } \\
\text { for patient at the } \\
\text { entrance }\end{array}$ & $\begin{array}{l}\text { Avoiding } \\
\text { transmission of } \\
\text { COVID to non- } \\
\text { COVID patients }\end{array}$ & $\begin{array}{l}\text { Head of Installation } \\
\text { Outpatient }\end{array}$ & $\begin{array}{l}\text { Blank } \\
\text { Screening }\end{array}$ & $\begin{array}{l}\text { Every } \\
\text { service hour } \\
\text { /ER }\end{array}$ & $\begin{array}{l}\text { Screening } \\
\text { officer }\end{array}$ & $\begin{array}{l}\text { Does not } \\
\text { incur } \\
\text { additional } \\
\text { costs }\end{array}$ \\
\hline 5 & $\begin{array}{l}\text { Moving the ER } \\
\text { isolation room to the } \\
\text { current ER screening } \\
\text { room and making } \\
\text { permanent partition }\end{array}$ & $\begin{array}{l}\text { Avoid transmission of } \\
\text { COVID to Non } \\
\text { COVID patients }\end{array}$ & $\begin{array}{l}\text { Head Outpatient } \\
\text { Installation, Head of } \\
\text { Room, Doctor on duty, } \\
\text { Nurse, Screening } \\
\text { officer }\end{array}$ & $\begin{array}{l}\text { Isolation } \\
\text { room does } \\
\text { not pass } \\
\text { the triage } \\
\text { room (Non } \\
\text { COVID) }\end{array}$ & $\begin{array}{l}\text { December } \\
\text { 2020/ER }\end{array}$ & $\begin{array}{l}\text { Head of } \\
\text { Outpatient } \\
\text { Installation, } \\
\text { Head of } \\
\text { Room }\end{array}$ & $\begin{array}{l}10,000,00 \\
0\end{array}$ \\
\hline 6 & $\begin{array}{l}\text { Making banners, } \\
\text { billboards, brochures } \\
\text { regarding COVID-19 }\end{array}$ & $\begin{array}{l}\text { Provide information } \\
\text { to patients and } \\
\text { visitors about COVID }\end{array}$ & $\begin{array}{l}\text { Head of Service } \\
\text { Affairs Medical, Head } \\
\text { of Finance, Head of } \\
\text { Outpatient Installation, } \\
\text { Head ofRoom }\end{array}$ & $\begin{array}{l}\text { Banner, } \\
\text { Billboards, } \\
\text { brochure }\end{array}$ & $\begin{array}{l}\text { December } \\
\text { 2020/ER }\end{array}$ & $\begin{array}{l}\text { Head of } \\
\text { Outpatient } \\
\text { Installation, } \\
\text { Head of } \\
\text { Room } \\
\end{array}$ & $2,500,000$ \\
\hline 7 & $\begin{array}{l}\text { Making banners about } \\
\text { the law and sanctions if } \\
\text { obstructing officers in } \\
\text { handling COVID }\end{array}$ & $\begin{array}{l}\text { Informing the Act and } \\
\text { sanctions against } \\
\text { persons who hinder } \\
\text { the work of the }\end{array}$ & $\begin{array}{l}\text { Head of Medical } \\
\text { Service Affairs, Head } \\
\text { of Finance, Head of } \\
\text { Outpatient Installation, } \\
\text { Head of Room, }\end{array}$ & Banner & $\begin{array}{l}\text { December } \\
\text { 2020/ER }\end{array}$ & $\begin{array}{l}\text { Head of } \\
\text { Outpatient } \\
\text { Installation, } \\
\text { Head of } \\
\text { Room } \\
\end{array}$ & $1,500,000$ \\
\hline
\end{tabular}

Plan of Action (POA) for number 1- 4 do not incure costs, meanwhile for POA number 4 costs 10 million rupiahs, for POA number 5 , costs two and a half million rupiahs and for POA number 7 costs 1,5 million rupiahs.

\subsection{Monitoring and Evaluation}

In guiding the implementation of activities in the field later, monitoring and evaluation activities are planned as shown in table 5 . 
Table 5. Monitoring and Evaluation Plan

\begin{tabular}{|c|c|c|c|c|}
\hline No & Activities & Input & Process & Output \\
\hline 1 & $\begin{array}{l}\text { Providing a } \\
\text { statement letter }\end{array}$ & $\begin{array}{l}\text { Head of Outpatient } \\
\text { Installation, Head of } \\
\text { Room, Screening } \\
\text { Officer, Statement } \\
\text { Letter The }\end{array}$ & $\begin{array}{l}\text { officer provides a } \\
\text { statement letter to all } \\
\text { patients Filling in the } \\
\text { statement by the patient }\end{array}$ & $\begin{array}{l}\text { The statement letter is } \\
\text { filled out honestly by the } \\
\text { patient }\end{array}$ \\
\hline 2 & $\begin{array}{l}\text { Providing an } \\
\text { explanation that }\end{array}$ & $\begin{array}{l}\text { Doctor } \\
\text { Inform Consent }\end{array}$ & $\begin{array}{l}\text { on dutyExplanation from } \\
\text { the doctor on duty to the }\end{array}$ & $\begin{array}{l}\text { Patient understands } \\
100 \% \text { that COVID is not }\end{array}$ \\
\hline 3 & $\begin{array}{l}\text { Creating a new } \\
\text { service flow } \\
\text { including } \\
\end{array}$ & $\begin{array}{l}\text { Head of Outpatient } \\
\text { Installation, Head of } \\
\text { Room, }\end{array}$ & Making a newnew & $\begin{array}{l}\text { patient service flow } \\
\text { There is apatient service } \\
\text { flow }\end{array}$ \\
\hline 4 & $\begin{array}{l}\text { Conducting } \\
\text { screening for } \\
\text { patient at the }\end{array}$ & $\begin{array}{l}\text { Officers, screening } \\
\text { forms }\end{array}$ & $\begin{array}{l}\text { Officers screen at the ER } \\
\text { entrance by filling in the } \\
\text { form }\end{array}$ & $\begin{array}{l}\text { Patients have been } \\
\text { placed based on COVID } \\
\text { or Non COVID }\end{array}$ \\
\hline 5 & $\begin{array}{l}\text { Moving the ER } \\
\text { isolation room } \\
\text { to the current } \\
\text { ER screening }\end{array}$ & $\begin{array}{l}\text { Head Outpatient } \\
\text { Installation, Head of } \\
\text { Room, }\end{array}$ & $\begin{array}{l}\text { Moving the isolation } \\
\text { room to the current } \\
\text { screening room and given } \\
\text { a permanent partition }\end{array}$ & $\begin{array}{l}\text { Separation of paths for } \\
\text { COVID and Non- } \\
\text { COVID patients }\end{array}$ \\
\hline 6 & $\begin{array}{l}\text { Making } \\
\text { banners, } \\
\text { billboards, } \\
\text { brochures and } \\
\end{array}$ & $\begin{array}{l}\text { Banners, billboards, } \\
\text { brochures, equipment } \\
\text { officers }\end{array}$ & $\begin{array}{l}\text { Patients/visitors can see } \\
\text { and read the information } \\
\text { on banners, billboards } \\
\text { and brochures }\end{array}$ & $\begin{array}{l}\text { Understanding about } \\
\text { COVID-19 }\end{array}$ \\
\hline 7 & $\begin{array}{l}\text { Making banners } \\
\text { about the law } \\
\text { and sanctions }\end{array}$ & $\begin{array}{l}\text { Head of Hospital, } \\
\text { Head of Outpatient } \\
\text { Installation, Head of } \\
\text { Room, Banner }\end{array}$ & $\begin{array}{l}\text { Patients/visitors read the } \\
\text { banner provided }\end{array}$ & $\begin{array}{l}\text { Understanding about } \\
\text { about the sanctions if } \\
\text { obstructing officers in } \\
\text { handling COVID }\end{array}$ \\
\hline
\end{tabular}

\section{Conclusion}

The service for COVID-19 patients in the ER at the Army Hospital has not been following the technical guidelines for hospital services during the adaptation period for new habits issued by the Ministry of Health. This is caused by several underlying factors, namely from the $5 \mathrm{M}$ aspect (Man, Method, Material, Money, Market). First, the patient is dishonest with the complaints he experiences and the rejection of the patient diagnosed with COVID (man). Second, the arrangement of the screening room in the ER is not following the service technical guidelines for handling COVID and there is no new COVID Patient service flow (method). Third, there is no portable $\mathrm{x}$-ray; there are no banners, billboards, brochures about COVID19 , and no banners about laws containing sanctions for people who hinder officers from working (materials). Fourth, limited funds for procuring portable X-rays (money), and fifth, the increase in the number of COVID patients is very fast compared to the beginning of the pandemic (the market).

The priority of alternative problem solving taken is by 1). Provide a statement letter for honesty of information from patients, 2) Educate the public that Covid is not a disgrace and does not need to be stigmatized, 3) Create a flow of services for Covid patients in the form of screening and triage actions 4) Conduct screening at the entrance and place COVID or Non-COVID patients 5) Making permanent insulation in the ER so that COVID patients do not come into contact with non-COVID patients. 6) Provide health promotion media in the form of banners, billboards, brochures related to Covid-19, and laws and sanctions for those who hinder officers in handling COVID.

\section{References}

1. Decree of the President of the Republic of Indonesia. Presidential Decree No. 12 of 2020 concerning the Determination of Non-Natural Disasters for the Spread of Corona Virus Disease 2019 as National Disasters. Fundam Nurs.;(1):1-2. Available https://peraturan.bpk.go.id/Home/Details/135718/ke ppres-no-12-tahun-2020 (2020)

2. Ministry of Health. Guidelines for Prevention and Control of COVID-19 5th Available https://covid19.go.id/storage/app/media/Protokol/20 20/Juli/REV-05_Pedoman_P2_COVID19_13_Juli_2020.pdf (2020)

3. Ministry of Health. Technical Guidelines for Hospital Services During the Adaptation of New Habits. 5, ARSI Journal. Available:

https://arxiv.org/pdf/1707.06526.pdf\%0Ahttps://ww w.yrpri.org\%0Ahttp://weekly.cnbnews.com/news/art icle.html?no=124000\%0Ahttps://www.fordfoundati on.org/\%0Ahttp://bibliotecavirtual.clacso.org.ar/Rep ublica_Dominicana/ccp/20120731051903/prep\%0A http://webpc.cia (2020)

4. World Health Organization. COVID-19 Risk Communication Materials for Health Service Facilities. WorldHealing Organs.Available from:https://covid19.go.id/p/protokol/pedomanpencegahan-dan-pengendalian-coronavirus-diseasecovid-19-revisi-ke-5 (2020).

5. Ministry of Health. Regulation of the Minister of Health of the Republic of Indonesia Number 47 of 2018 concerning Emergency Services.

Available from: http://ieeeauthorcenter.iee.org/wp- 
content/uploads/IEEE-Reference-

Guide.pdf\%0Ahttp://wwwlib.murdoch.edu.au/find/c itation/ieee.html\%0Ahttps://doi.org/10.1016/j.cie.20 19.07.022\%0Ahttps://github.com/ethereum/wiki/wik i/White-Paper\%0Ahttps://tore.tuhh.de/handle/11420 (2018).

6. Indonesian Ministry of Health. Hospital Emergency Room (IGD) Standards. Minister of Health of the Republic of Indonesia Regulation of the Minister of Health of the Republic of Indonesia. 1-29.

Available from:

http://hukor.kemkes.go.id/uploads/produk_hukum/P
MK_No_47_Th_2018_ttg_Emergency_Services.pd $\mathrm{f}(2009)$.

7. Health England P. COVID-19: Guidance for maintaining services within health and care settings Infection prevention and control recommendations Version 1.2.;1-49.

Available

https://assets.publishing.service.gov.uk/government/ uploads/system/uploads/attachment_data/file/99092 3/20210602_Infection_Prevention_and_Control_Gui dance_for_maintaining_services_with_H_and_C_set tings_1_.pdf.(2021). 